\title{
Taxonomy of duckweeds (Lemnaceae), potential new crop plants
}

\author{
K. Sowjanya Sree', Manuela Bog ${ }^{2}$, Klaus-Juergen Appenroth ${ }^{3 *}$ \\ ${ }^{1}$ Amity Institute of Biotechnology, Amity University Uttar Pradesh, Noida, India, ${ }^{2}$ University of Regensburg, Institute of Plant Sciences, \\ Regensburg, Germany, ${ }^{3}$ Institute of General Botany and Plant Physiology, University of Jena, Jena, Germany
}

\section{A B S TR A C T}

\begin{abstract}
Duckweeds are increasingly gaining interest because of their potential as a new aquaculture crop. In the present era of high throughput research, duckweed taxonomy has to be emphasized in order to support and strengthen scientific communication and commercial application. Since the publication of the fundamental monograph on Lemnaceae by E. Landolt in 1986, a number of changes have taken place in terms of their taxonomic position and nomenclature, which we summarize in this review. We report here about the systematic position of this plant family and the changes in its organization. Three additional species were identified; one new genus and subsequently one of the species was re-defined after the publication of the key of determination in 1986. At present Lemnaceae comprises of 37 species grouped into five genera. We envisage that this review will serve as a compilation of all these recent revisions, describing the state of art of duckweed systematics.
\end{abstract}

Keywords: Aquaculture; Duckweed; Lemnaceae; Taxonomy; Crop plant

\section{INTRODUCTION}

The present "blooming era" of "resurgence of duckweed research and applications" (Zhao et al., 2012; Lam et al., 2014; Appenroth et al., 2015b) is based mainly on their high potential for practical application. Lemnaceae comprises one of the fastest growing angiosperms (Sree et al., 2015c; Ziegler et al., 2015). In some Asian countries, duckweeds have been used for human nutrition for generations (Bhanthumnavin and McGarry, 1971; cf. van der Spiegel et al., 2013), because of their high protein content (Appenroth et al., 1982; Cheng and Stomp, 2009). Duckweeds have the potential to replace soya bean products at least partially as a source of protein. As demonstrated by several projects, duckweeds proved to be advantageous when fed to domesticated animals e.g., cattle, sheep, horses, rabbits (reviews in Landolt and Kandeler, 1987; Cheng and Stomp, 2009), poultry and water fowls (Muztar et al., 1979; Anderson et al., 2011), fish (Hassan and Edwards, 1992; Pipalova, 2003), and pigs (Van et al., 1997). Apart from their use as food and feed, duckweed biomass with high starch content produced under suitable cultivation conditions (Sree and
Appenroth, 2014; Sree et al., 2015a, b) can be used as a raw material for biofuel and biogas plants (Jain et al., 1992; Su et al., 2014; Cui and Cheng, 2015). This would substantially replace the use of food crops that are grown in arable lands as raw materials for biofuel production. Taken together, plants of this family have the potential as new crop plants.

Duckweeds, monocotyledonous aquatic plants, are represented by 37 species (Appenroth et al., 2013). This number is often cited incorrectly probably because of the following reason. In the year 2000, it became clear that Lemna ecuadoriensis is a synonym of L. obscura (Austin) Daubs (Landolt, 2000). But by mistake (personal correspondence to KJA), this merger was not considered in Les et al. (2002) and also not in Tippery et al. (2015). As a result, the total number of duckweed species was mentioned as 38 instead of 37 , creating confusion to the readers. The 37 species are categorized into five well-defined genera (Fig. 1, Table 1): Spirodela (2 species), Landoltia (1), Lemna (13), Wolffella (10) and Wolffia (11) (Appenroth et al., 2013). These aquatic angiosperms are cosmopolitan in distribution except for some endemic species (Landolt, 1986).

\footnotetext{
${ }^{*}$ Corresponding author:

Klaus-Juergen Appenroth, Institute of General Botany and Plant Physiology, University of Jena, Dornburger Str. 159, 07743 Jena, Germany. E-mail: Klaus.Appenroth@uni-jena.de 


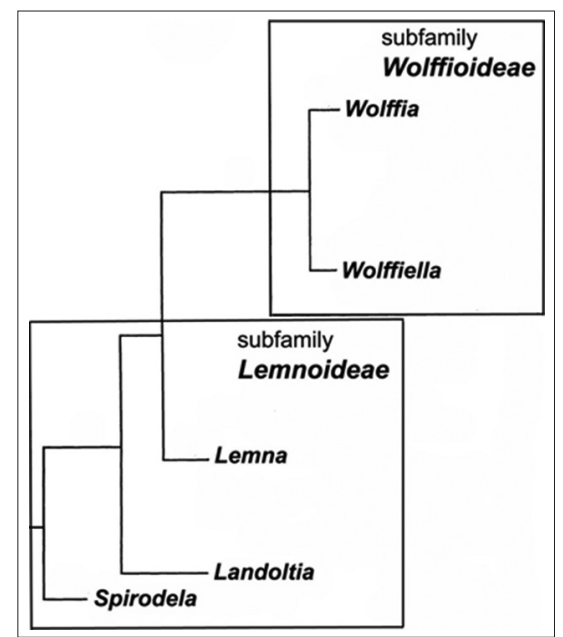

Fig 1. Internal structure of the family: Lemnaceae. The relation of genera and subfamilies based on Les et al. (2002) and Tippery et al. (2015).

Elias Landolt from ETH Zurich, Switzerland has collected duckweeds from all over the world since the mid-1950s and established a duckweed stock collection (Landolt, 1957; Appenroth et al., 2015a) which originally exceeded one thousand clones. Based mainly on morphological investigations, he published a "key of determination" of duckweeds (Landolt, 1980) which was later slightly modified in the first part of his famous monograph (Landolt, 1986). Within the last three decades, quite a number of changes have been introduced to taxonomic classification of duckweeds in comparison to the published key. Moreover, molecular taxonomy and barcoding of duckweed species (Wang et al., 2010; Bog et al., 2010, 2013, 2015; Borisjuk et al., 2015) has made huge progress and it aids in identification of duckweed species. However, it is not practically and economically viable to determine each of the collected duckweed clones by Amplified Fragment Length Polymorphism (AFLP) or by sequencing of DNA markers. Therefore, determination of duckweed species based on their morphology remains crucial for their identification. An update to the "key of determination" of all the duckweed species known to date is a prerequisite to facilitate accuracy in communication amongst researchers in academia and industry, and also entrepreneurs in this field, especially keeping in view the practical applications of duckweeds.

In this review we discuss the taxonomic position of duckweeds and the classification changes made since the publication of Landolt's monograph in 1986 (Table 2). This revision shall help students and newcomers to the field of duckweed research and applications to become quickly acquainted with this expanding field and to use the accurate terms and nomenclature.
Table 1: Presently accepted genera and species of the plant family Lemnaceae Dumort

\begin{tabular}{|c|c|c|}
\hline Subfamily & Genera & Species \\
\hline \multirow[t]{16}{*}{$\begin{array}{l}\text { Lemnoideae } \\
\text { Engl. }\end{array}$} & $\begin{array}{l}\text { Spirodela } \\
\text { Schleid. }\end{array}$ & S. polyrhiza (L.) Schleid. \\
\hline & & S. intermedia W.Koch \\
\hline & $\begin{array}{l}\text { Landoltia } \\
\text { Les \& } \\
\text { Crawford }\end{array}$ & L. punctata (G.Mey.) Les \& D.J.Crawford \\
\hline & Lemna L. & L. disperma Hegelm. \\
\hline & & L. gibba L. \\
\hline & & L. japonica Landolt \\
\hline & & L. minor L. \\
\hline & & L. obscura (Austin) Daubs \\
\hline & & L. turionifera Landolt \\
\hline & & L. trisulca L. \\
\hline & & L. aequinoctialis Welw. \\
\hline & & L. perpusilla Torr. \\
\hline & & L. tenera Kurz \\
\hline & & L. minuta Kunth \\
\hline & & L. valdiviana Phil. \\
\hline & & L. yungensis Landolt \\
\hline \multirow{21}{*}{$\begin{array}{l}\text { Wolffioideae } \\
\text { Engl. }\end{array}$} & Wolffiella & W. caudata Landolt \\
\hline & & W. denticulata (Hegelm.) Hegelm. \\
\hline & & W. gladiata (Hegelm.) Hegelm. \\
\hline & & W. lingulata (Hegelm.) Hegelm. \\
\hline & & W. neotropica Landolt \\
\hline & & W. oblonga (Phil.) Hegelm. \\
\hline & & W. welwitschii (Hegelm.) Monod \\
\hline & & W. rotunda Landolt \\
\hline & & W. hyalina (Delile) Monod \\
\hline & & W. repanda (Hegelm.) Monod \\
\hline & $\begin{array}{l}\text { Wolffia } \\
\text { Horkel ex } \\
\text { Schleid. }\end{array}$ & W. angusta Landolt \\
\hline & & W. arrhiza (L.) Horkel ex Wimm. \\
\hline & & W. columbiana H.Karst. \\
\hline & & W. cylindracea Hegelm. \\
\hline & & W. elongata Landolt \\
\hline & & W. globosa (Roxb.) Hartog \& Plas \\
\hline & & W. neglecta Landolt \\
\hline & & W. australiana (Benth.) Hartog \& Plas \\
\hline & & W. borealis (Engelm. ex Hegelm.) Landolt \\
\hline & & W. brasiliensis Wedd. \\
\hline & & W. microscopica (Griff.) Kurz \\
\hline
\end{tabular}

Taxonomic position of the family Lemnaceae

Duckweed species are monophyletic with those of the Araceae (Cabrera et al., 2008; Cusimano et al., 2011). However, the branching appears to have started about $104 \mathrm{Ma}$ ago in the Early Cretaceous when the breakup of Pangea was in its final stage (Nauheimer et al., 2012). This is one reason why we prefer keeping Lemnaceae as a family of its own (Appenroth et al., 2015a). The monophyly does not necessarily mean that duckweeds have to be integrated into the family of Araceae and be treated as a subfamily Lemnoideae, as preferred e.g. by Nauheimer et al. (2012). 
Table 2: Newly discovered species and revised nomenclature after the publication of the duckweed monograph by Landolt (1986)

\begin{tabular}{llll}
\hline S. No. & Presently accepted nomenclature & Old nomenclature (not valid=synonym) & Reference \\
\hline 1 & Landoltia punctata (G.Mey.) Les \& D.J.Crawford & Spirodela punctata & Les and Crawford (1999) \\
& & Spirodela oligorrhiza & Li and Landolt (2010) \\
& & Spirodela sichuanensis & Appenroth et al. (1990) \\
3 & Spirodela polyrhiza (L.) Schleid. & Spirodela polyrrhiza & Landolt (1986) \\
& Lemna aequinoctialis Welw. & Lemna paucicostata & Borisjuk et al. (2015) \\
4 & & Lemna aoukikusa & Reveal (1990) \\
5 & Lemna minuta Kunth & Lemna minuscula & Landolt (2000) \\
6 & Lemna obscura (Austin) Daubs & Lemna ecuadoriensis & Landolt (1986) \\
7 & Lemna valdiviana Phil. & Lemna valdesiana & Landolt (1992) \\
8 & Wolffiella caudata Landolt & New species & Landolt (1994) \\
9 & Wolffia neglecta Landolt & New species & Landolt (1994) \\
\hline
\end{tabular}

One can separate the small group of Protoaraceae together with Lemnaceae from the "true Araceae" (as these two groups are the most basal elements in this group), which results in three monophyletic plant families, i.e. true Araceae, Lemnaceae and Protoaraceae (Appenroth et al., 2015a). The following additional arguments speak in favour of designating Lemnaceae as a family on its own (Appenroth et al., 2013): (1) The notion to unify Araceae and Lemnaceae originated from a certain similarity between Pistia spp. and some duckweeds, especially Spirodela polyrbiza L. (Schleid.) (Hooker and Brown, in Smith, 1824). On the basis of more recent morphological and molecular investigations (Cusimano et al., 2011), it is now clear that this similarity is only superficial. (2) The characteristics of the members of Lemnaceae which are similar to those of Araceae at the morphological, anatomical or biochemical levels are not only restricted to Araceae but are similar in all Alismatales. (3) All species belonging to Lemnaceae together form a well-defined unit on morphological, biochemical and habitat bases.

The current systematic investigations into the evolutionary and taxonomic relationships between the five genera of Lemnaceae are represented in Fig. 1 (cf. Les et al., 2002; Tippery et al., 2015) and the classification of these five genera into 37 species has been depicted in Table 1.

\section{Newly discovered species}

The following three species were discovered after 1986:

\section{Wolffiella caudata Landolt}

Wolffiella caudata was first described by E. Landolt in 1992. It was found to grow in the southwestern part of the Amazon basin within the inundation area of the tributary rivers, e.g. Yacuma and Tahuamanu, in Bolivia. More information on its identification can be found in Landolt (1992). A chemotaxonomic study of the genus Wolffiella including $W$. caudata was performed by Crawford et al. (1997) based on the allozyme profiles. Barcoding (Wang et al., 2010; Borisjuk et al., 2015) and a detailed molecular taxonomic investigation of this species based on AFLP and plastidic marker sequences (unpublished data; Bog, Sree and Appenroth) has been carried out recently together with other species of the genus Wolffiella. These investigations further support its species identity.

\section{Wolffia cylindracea Hegelm.}

Wolffia cylindracea was found in seasonal waters of winterdry subtropical to tropical regions of Africa, south of the equator, e.g. Angola (Landolt, 1994). Although this species was first described by C.F. Hegelmaier as early as 1868 (Hegelmaier, 1868), researchers of the later century did not consider it and incorporated it into the species W. globosa (Roxb.) Hartog \& Plas (Daubs, 1965; Landolt, 1986). The distinctness of the African clones of $W$. globosa in the chemotaxonomic investigations led to the rediscovery of this group of African plants as a separate species, $W$. cylindracea, as already suggested by Hegelmaier (Landolt, 1994; Crawford and Landolt, 1995). The molecular taxonomic studies on this species also clearly distinguish this species from its relatives (Bog at al., 2013; Borisjuk et al., 2015).

\section{Wolffia neglecta Landolt}

Wolffia neglecta (Landolt, 1994) was found in the winter-dry subtropical to tropical regions of India (e.g. Rajasthan), Pakistan, and Sri Lanka and probably exists in seasonal waters. The classification of these plants as new species was supported by chemotaxonomic methods (Crawford and Landolt, 1995).

Detailed morphological description of $W$. cylindracea and $W$. neglecta annexed with photographs and very useful drawings are presented in Landolt (1994).

\section{Changes in the species nohmenclature}

It is worth mentioning that in plant systematics the term "synonym" has an unusual meaning. It describes the same species (which would be in agreement with the common usage of the term) but also means that this name is no 
longer valid and should not be used. We would like to cite from a letter of W. S. Hillman published by E. Landolt (1986, p. 444): "When the late Dr. Wm.S. HILLMAN (Brookhaven, NY) learned that the name L. paucicostata had to be changed again, he wrote to me in an understandable reaction: "I am filled with horror or laughter (I am not sure which) at the thought of again changing the name under which we write articles about poor old 6746 and its brethren. And the names get worse and worse for the ordinary (English-speaking anyway) person to handle: perpusilla -" paucicostata -" aequinoctialis. And please, I do beg of you, conceal the reference from me as long as possible, since people who read the physiological literature tend to be intolerant of such things"." Although this reaction is understandable, results of the investigations in the field of plant systematics should be respected by other plant scientists.

The most dramatic change in duckweed terminology took place when the molecular taxonomic investigations of Les and Crawford (1999) resulted in the decision to create a new genus, Landoltia Les \& D.J.Crawford. As a consequence, Spirodela punctata (formerly termed as Spirodela oligorrbiza) was renamed as Landoltia punctata (G.Mey.) Les \& D.J.Crawford, and S. oligorrbiza and S. punctata became synonyms of $L$. punctata. This change in nomenclature was challenged by Ward (2011). Because the type specimen described as Lemna punctata by G. F. W. Meyer was lost, he suggested a neotypification but with Spirodela intermedia as a type. As already stressed by E. Landolt (cited in Wiersema, 2015) this would lead to considerable confusion in duckweed nomenclature (cf. for the genus Spirodela in Plant List, Version 1.1, 2013, http:/ /www.theplantlist.org). More recently, Wiersema (2015) made it clear that the valid name of this species is Landoltia punctata. However, such a drastic change in botanical nomenclature has the unfortunate consequence that the old but crucial and basic research (e.g. Mattoo et al., 1984; Greenberg et al., 1987) published under the old name of the species (e.g. Spirodela oligorrbiza) cannot be retrieved by the internet search machines using the new nomenclature (e.g., Landoltia punctata).

Another interesting change is the spelling of the species name, Spirodela polyrbiza. Landolt (1986) considered this spelling of the species to be an orthographic mistake of the term polyrrbiza with two 'r's and used the spelling Spirodela polyrrbiza. But as pointed out by Appenroth et al. (1990), Spirodela polyrbiza with one ' $\mathrm{r}$ ' is the valid name as written by its author von Linné (Linnaeus, 1753).

Two of the Lemna species should be mentioned in this context. The first one is Lemna aequinoctialis Welw. Its synonym, Lemna paucicostata, which was replaced many years ago is still being used and the species name is wrongly cited (e.g. Murata et al., 2014). Lemna aonkikusa (as mentioned in Yamaga et al., 2010) is also a synonym of Lemna aequinoctialis (Landolt, 1986). This decision was recently confirmed by Borisjuk et al. (2015) based on the plastidic sequence analysis. In a second case, Reveal (1990) found out that there was already an older and valid name for Lemna minuscula. As a consequence and following the rules of plant systematics, the name of the species Lemna minuscula had to be changed to Lemna minuta Kunth and the term $L$. minuscula became a synonym. It is worth to mention that the species of the genus Lemna are characterized by the presence of one root (Landolt, 1980). The names Lemna polyrbiza and Lemna arrbiza are therefore not valid (Landolt, 1986). The valid names are Spirodela polyrbiza and Wolffia arrbiza Horkel ex Wimm. (Iamonico and Iberite, 2014). Iamonico and Iberite (2014) also lectotypified the two Linnaean names: Lemna polyrbiza and Lemna arrbiza. Although invalid, the first one is still being used (e.g. Lemna polyrbiza in Bairagi et al., 2002; Lemna polyrrbiza in John et al., 2008). Apart from the fact that these names are invalid, they are in evident conflict with the meaning of the terms "polyrhiza" (= many roots) or "arrhiza" (= rootless) under the genus Lemna.

As a supplementary material we have compiled all the synonyms of the 37 duckweed species, which we became aware over the years. The valid names are given in each case. The Plant List (Version 1.1, 2013, http:/ / www.theplantlist. org), a working list of all known plant species, mentions two additional accepted duckweed species names: Spirodela sichuanensis M.G.Liu \& K.M.Xie and Lemna valdesiana S.Watson. However, both species were reviewed by Landolt and were treated as synonyms for Landoltia punctata (Li and Landolt, 2010) and Lemna valdiviana (Landolt, 1986), respectively.

\section{Registration of clones}

To facilitate comparison of the research results within different duckweed labs, it has been suggested to register the clones of the duckweed species and obtain a four-digit code introduced by Elias Landolt (ISCDRA Newsletter No. 1; http://lemnapedia.org/wiki/International_ registration_of_duckweed_clones). This code can be cited in scientific communications for easy reference. Registration can be done at the home page of the Rutgers Duckweed Stock Cooperative (Head: Prof. Dr. Eric Lam, Rutgers, State University of New Jersey, New Brunswick, USA: http://www.ruduckweed.org/).

\section{CONCLUSIONS}

Use of accurate scientific nomenclature of the duckweed species needs to be stressed in view of the considerable 
number of changes in duckweed systematics in the recent past. Efforts should be made to disseminate this up-todate information to duckweed researchers as well as to the general readers. In general interest and convenience of both the authors and the readers, it is recommended that the synonym (invalid old name of a species) of a duckweed species be mentioned in braces at the first mention of the new name of the duckweed species in a text. With the current advancements in the field of molecular biology, barcoding and molecular taxonomy of Lemnaceae members have already reached a considerable level. Nevertheless, morphological identification of duckweeds still remains significantly important and cannot be superseded. For instance, Wolffia neglecta, a species described by E. Landolt on a morphological basis, can hardly be separated out as a species on its own using the methods of molecular taxonomy (Bog et al., 2013). On the other hand, molecular taxonomy aids in investigating some of the minute details. The term Lemna yungensis Landolt must be specially mentioned. This species was introduced mainly by eco-geographic reasons because it was discovered on wet rocks that are in permanent contact with flowing waters (Landolt, 1998). However, according to our investigations, the morphological differences between L. yungensis and L. valdiviana Phil. are not very distinct and the molecular analysis also does not provide markers for a clear differentiation between the two species (Bog et al., 2010; Borisjuk et al., 2015). In-depth molecular analysis might provide a substantial basis for further conclusions in this respect.

\section{Author's contributions}

All three authors discussed together the idea to support the "International Steering Committee on Duckweed Research and Applications" in creating scientific standards for duckweed research. Also all three authors contributed by evaluating relevant literature. KJA made a first draft which was modified by KSS and MB.

\section{REFERENCES}

Anderson, K. E., Z. Lowman, A. M. Stomp and J. Chang. 2011. Duckweed as a feed ingredient in laying hen diets and its effect on egg production and composition. Int. J. Poult. Sci. 10: 4-7.

Appenroth, K. J., H. Augsten, B. Liebermann and H. Feist. 1982. Effects of light quality on amino acid composition of proteins in Wolffia arrhiza (L.) WIMM. Using a specially modified Bradford method. Biochem. Physiol. Pflanzen. 177: 251-258.

Appenroth, K. J., N. Borisjuk and E. Lam. 2013. Telling duckweed apart: Genotyping technologies for Lemnaceae. Chin. J. Appl. Environ. Biol. 19: 1-10.

Appenroth, K. J., D. J. Crawford and D. H. Les. 2015a. After the genome sequencing of duckweed - How to proceed with research on the fastest growing angiosperm? Plant Biol. 17 Suppl. 1: 1-4.
Appenroth, K. J., W. Hertel and H. Augsten. 1990. Phytochrome control of turion formation in Spirodela polyrhiza L. Schleiden. Ann. Bot. 66: 163-168.

Appenroth, K. J., K. S. Sree, T. Fakhoorian and E. Lam. 2015b. Resurgence of duckweed research and applications: Report from the $3^{\text {rd }}$ International duckweed conference. Plant Mol. Biol. 89: 647-654.

Bairagi, A., K. S. Ghosh, S. K. Sen and A. K. Ray. 2002. Duckweed (Lemna polyrhiza) leaf meal as a source of feedstuff in formulated diets for rohu (Labeorohita Ham.) fingerlings after fermentation with a fish intestinal bacterium. Bioresour. Technol. 85: 17-24.

Bhantumnavin, K. and M. G. McGarry. 1971. Wolffia arrhiza as a possible source of inexpensive protein. Nature. 232: 495.

Bog, M., H. Baumbach, U. Schween, F. Hellwig, E. Landolt and K. J. Appenroth. 2010. Genetic structure of the genus Lemna L. (Lemnaceae) as revealed by amplified fragment length polymorphism. Planta. 232: 609-619.

Bog, M., U. Lautenschlager, M. F. Landrock, E. Landolt, F. Fuchs, K. S. Sree, C. Oberprieler and K. J. Appenroth. 2015. Genetic characterization and barcoding of taxa in the genera Landoltia and Spirodela (Lemnaceae) by three plastidic markers and amplified fragment length polymorphism (AFLP). Hydrobiologia. 749: 169-182

Bog, M., P. Schneider, F. Hellwig, S. Sachse, E. Z. Kochieva, E. Martyrosian, E. Landolt and K. J. Appenroth. 2013. Genetic characterization and barcoding of taxa in the genus Wolffia Horkel ex Schleid. (Lemnaceae) as revealed by two plastidic markers and amplified fragment length polymorphism (AFLP). Planta. 237: 1-13.

Borisjuk, N., P. Chu, R. Gutierrez, H. Zhang, K. Acosta, N. Friesen, K. S. Sree, C. Garcia, K. J. Appenroth and E. Lam. 2015 Assessment, validation and deployment strategy of a two barcode protocol for facile genotyping of duckweed species. Plant Biol. 17 Suppl. 1: 42-49.

Cabrera, L. I., G. A. Salazar, M. W. Chase, S. J. Mayo, J. Bogner and P. Davila. 2008. Phylogenetic relationships of aroids and duckweeds (Araceae) inferred from coding and noncoding plastid DNA. Am. J. Bot. 95: 1153-1165.

Cheng, J. J. and A. M. Stomp. 2009. Growing duckweed to recover nutrients from wastewaters and for production of fuel ethanol and animal feed. Clean. 37: 17-26.

Crawford, D. J. and E. Landolt. 1995. Allozyme divergence among species of Wolffia (Lemnaceae). Plant Syst. Evol. 197: 59-69.

Crawford, D. J., E. Landolt, D. H. Les and E. Tepe. 1997. Allozyme variation and the taxonomy of Wolffiella. Aquat. Bot. 58: 43-54.

Crawford, D. J., E. Landolt, D. H. Les and E. Tepe. 1997. Allozyme variation and the taxonomy of Wolffiella (Lemnaceae). Aquat. Bot. 58: 43-54.

Cui, W. and J. J. Cheng. 2015. Growing duckweed for biofuel production: A review. Plant Biol. 17 Suppl. 1: 16-23.

Cusimano, N., J. Bogner, S. J. Mayo, P. C. Boyce, S. A. Y. Wong, M. Hesse, W. L. A. Hetterscheid, R. C. Keating and J. C. French. 2011. Relationships within the Araceae: Comparison of morphological patterns with molecular phylogeny. Am. J. Bot. 98: 654-668.

Daubs, E. H. 1965. A monograph of Lemnaceae. In: Illinois Biological Monographs, Vol. 34. University of Illinois Press, Urbana.

Greenberg, B. M., V. Gaba, A. K. Mattoo and M. Edelman. 1987. Identification of a primary in vivo degradation product of the rapidly-turn-over 32-KD protein of photosystem-II. EMBO J. 6 : 2865-2869.

Hassan, M. S. and P. Edwards. 1992. Evaluation of duckweed 
(Lemna perpusilla and Spirodela polyrrhiza) as feed for Nile tilapia (Oreochromisniloticus). Aquaculture. 104: 315-326.

Hegelmaier, F. 1868. Die Lemnaceen. Eine Monographische Untersuchung, Leipzig, Verlag Wilhelm Engelmann.

Iamonico, D. and M. Iberite. 2014. Lectotypification of the Linnaean names Lemna arrhiza and L. polyrhiza (Araceae). Taxon. 63: 1314-1315.

Jain, S. K., G. S. Gujral, N. K. Jha and P. Vasudevan. 1992. Production of biogas from Azollapinnata R.Br and Lemna minor L.: Effect of heavy metal contamination. Bioresour. Technol. 41: 273-277.

John, R., P. Ahmad, K. Gadgil and S. Sharma. 2008. Effect of cadmium and lead on growth, biochemical parameters and uptake in Lemna polyrrhiza L. Plant Soil. Environ. 54: 262-270.

Lam, E., K. J. Appenroth, T. Michael, K. Mori and T. Fakhoorian. 2014. Duckweed in bloom: The $2^{\text {nd }}$ International Conference on Duckweed Research and Applications Heralds the Return of A Plant Model for Plant Biology. Plant Mol. Biol. 84: 737-742.

Landolt, E. 1957. Physiological and ecological investigations on Lemnaceae. Ber Schweiz. Bot. Ges. 67: 271-410.

Landolt, E. 1980. Key to the determination of taxa within the family of Lemnaceae. Veröffentlichunge Geobot. Inst. ETH. Stiftung Ruebel Zurich. 70: 13-21.

Landolt, E. 1986. The family of Lemnaceae - A monographic study. Vol. 1. Biosystematic Investigations in the Family of Duckweeds (Lemnaceae). Veröffentlichungen des Geobotanischen Institutes der ETH, Stiftung Ruebel, Zurich.

Landolt, E. 1992. Wolffiella caudata, a new Lemnaceae species from the Bolivian Amazon region. Ber. Geobot. Inst. Eidgenössischen Technischen Hochschule, Stiftung Ruebel. 58: 121-123.

Landolt, E. 1994. Taxonomy and ecology of the section Wolffia of the genus Wolffia (Lemnaceae). Ber. Geobot. Inst. ETH. Stiftung Ruebel. 60: 137-151.

Landolt, E. 1998. Lemna yungensis, a new duckweed species from rocks of the Andean Yungas in Bolivia. Bull. Geobot. Inst. ETH. 64: 15-21.

Landolt, E. 2000. Contribution on the Lemnaceae of ecuador. Fragmenta Floristica et Geobotanica 45: 221-237.

Landolt, E. and R. Kandeler. 1987. The family of Lemnaceae - A monographic study. Veroeffentlichungen des Geobotanischen Institutes ETH, Vol. 2. Stiftung Ruebel, Zurich, Switzerland.

Les, D. H. and D. J. Crawford. 1999. Landoltia (Lemnaceae) a new genus of duckweeds. Novon. 9: 530-533.

Les, D. H., D. J. Crawford, E. Landolt, J. D. Gabel and R. T. Kimball. 2002. Phylogeny and systematics of Lemnaceae, the duckweed family. Syst. Bot. 27: 221-240.

Li, H. and E. Landolt. 2010. Lemnaceae. Flora China. 23: 80-83.

Linnaeus, C. 1753. Species Plantarum, Vol. 2. Holmiae [Stockholm]: Impensis Laurentii Salvii. http://dx.doi.org/10.5962/bhl.title.669.

Mattoo, A. K., H. Hoffmanfalk, J. B. Marder and M. Edelman. 1984. Regulation of protein-metabolism - Coupling of photosynthetic electron-transport to in vivo degradation of the rapidly metabolized 32-kilodalton protein of the chloroplast membranes. P. Natl. Acad. Sci. U S A. 81: 1380-1384.

Murata, A., R. Akaike, T. Kawahashi, R. Tsuchiya, H. Takemoto, T. Ohnishi, Y. Todoroki, N. Mase, M. Yokoyama, K. Takagi, P. Winterhalter and N. Watanabe. 2014. Characterization of flower - Inducing compound in Lemna paucicostata exposed to drought stress. Tetrahedron. 70: 4969-4976.

Muztar, A. J., S. J. Slinger and J. H. Burton. 1979. Metabolizable energy content of freshwater plants in chicken and ducks. Poult. Sci. 56: 1893-1899.
Nauheimer, L., D. Metzler and S.S. Renner. 2012. Global history of the ancient monocot family Araceae inferred with models accounting for past continental positions and previous ranges based on fossils. New Phytol. 195: 938-950.

Pipalova, I. 2003. Grass carp (Ctenopharyngodon idella) grazing on duckweed (Spirodela polyrhiza). Aquacult. Int. 11: 325-336.

Reveal, J. L. 1990.The neotypification of Lemna minuta Humb., Bonpl. \& Kunth, an earlier name for Lemna minuscula Herter (Lemnaceae). Taxon. 39: 328-330.

Smith, J. E. 1824. The English flora. Vol. 1. Longman, Hurst, Rees, Orme, Brown \& Green, London, p. 31.

Spiegel, van der M., M.Y. Noordam and H.J. van der Fels-Klerx. 2013. Safety of novel protein sources (Insects, Microalgae, Seaweed, Duckweed, and Rapeseed) and legislative aspects for their application in food and feed production. Compr. Rev. Food Sci. F. 12: 662-678.

Sree, K. S., K. Adelmann, C. Garcia, E. Lam and K. J. Appenroth. 2015a. Natural variance in salt tolerance and induction of starch accumulation in duckweeds. Planta. 241: 1395-1404.

Sree, K. S. and K. J. Appenroth. 2014. Increase of starch accumulation in the duckweed Lemna minor under abiotic stress. Albanian J. Agric. Sci. 13 Special Edition: 11-14.

Sree, K. S., Á. Keresztes, B. Mueller-Roeber, R. Brandt, M. Eberius, W. Fischer and K. J. Appenroth. 2015b. Phytotoxicity of cobalt ions on the duckweed Lemna minor - Morphology, ion uptake, and starch accumulation. Chemosphere. 131: 149-156.

Sree, K. S., S. Sudakaran and K. J. Appenroth. 2015c. How fast can angiosperm grow? Species and clonal diversity of growth rates in the genus Wolffia (Lemnaceae). Acta Physiol. Plant. 37(204). DOI: 10.1007/s11738-015-1951-3.

Su, H. F., Y. Zhao, J. Jiang, Q. L. Lu, Q. Li, Y. Luo, H. Zhao and M. L. Wang. 2014. Use of duckweed (Landoltia punctata) as a fermentation substrate for the production of higher alcohols as biofuels. Energ. Fuel. 28: 3206-3216.

Tippery, N. P., D. H. Les and D. J. Crawford. 2015. Evaluation of phylogenetic relationships in Lemnaceae using nuclear ribosomal data. Plant Biol. 17 Suppl. 1: 50-58.

Van, B. H., L. Men, V. Son and T. R. Preston. 1997. Duckweed (Lemna spp.) as protein supplement in an ensiled cassava root diet for fattening pigs. Livestock Res. Rural Dev. 9: 1-15.

Wang, W., Y. Wu, Y. Yan, M. Ermakova, R. Kerstetter and J. Messing. 2010. DNA barcoding of the Lemnaceae, a family of aquatic monocots. BMC Plant Biol. 10: 205.

Ward, D. B. 2011. Spirodela oligorrhiza (Lemnaceae) is the correct name for the lesser greater duckweed. J. Bot. Res. Inst. Texas. 5: 197-203.

Wiersema, J. H. 2015. Application of the name Lemna punctata G. Mey., The type of Landoltia Les \& D. J. Crawford. Plant Biol. 17 Suppl. 1: 5-9.

Yamaga, F., K. Washio and M. Morikawa. Sustainable biodegradation of phenol by Acinetobacter calcoaceticus P23 isolated from the rhizosphere of duckweed Lemna aoukikusa. Environ. Sci. Technol. 44: 6470-6474.

Zhao, H., K. J. Appenroth, L. Landesman, A. A. Salmean and E. Lam. 2012. Duckweed rising at Chengdu: Summary of the $1^{\text {st }}$ International Conference on Duckweed Application and Research. Plant Mol. Biol. 78: 627-632.

Ziegler, P., K. Adelman, S. Zimmer, C. Schmidt and K. J. Appenroth. 2015. Relative in vitro growth rates of duckweeds (Lemnaceae) - The most rapidly growing higher plants. Plant Biol. 17 Suppl. 1: 33-41. 


\title{
SUPPLEMENTARY MATERIAL
}

\section{Synonyms of Lemnaceae species}

\author{
Landoltia punctata (G.Mey.) Les \& D.J.Crawford (Novon 9: 532, 1999) \\ Lemna punctata G.Mey. (Prim. Fl. Esseq. 262, 1818); \\ Lemna gibba Blanco (Fl. Filip. 672, 1837); \\ Lemna oligorrhiza Kurz (J. Linn. Soc. Bot. 9: 267, 1866); \\ Lemna melanorrbiza F. Muell. ex Kurz (J. Bot. 5: 115, 1867); \\ Lemna pleiorrbiza F. Muell. ex Kurz (J. Bot. 5: 115, 1867); \\ Spirodela oligorrbiza (Kurz) Hegelm. (Lemnac. 147, 1868); \\ Lemna pusilla Hegelm. (Lemnac. 147, 1868); \\ Lemna javanica F.A.Bauer ex Hegelm. (Lemnac. 150, 1868); \\ Spirodela oligorrbiza var. melanorrbiza (F. Muell. ex Kurz) Hegelm. (Lemnac. 148, 1868); \\ Spirodela oligorrbiza var. pleiorrbiza (F. Muell. ex Kurz) Hegelm. (Lemnac. 149, 1868); \\ Spirodela oligorrbiza var. pusilla Hegelm. (Lemnac. 149, 1868); \\ Spirodela oligorrbiza var. javanica Hegelm. (Lemnac. 150, 1868); \\ Spirodela melanorrbiza (F. Muell. ex Kurz) Hegelm. (Bot. Jahrb. Syst. 21: 287, 1895); \\ Spirodela pusilla (Hegelm.) Hegelm. (Bot. Jahrb. Syst. 21: 287, 1895); \\ Spirodela javanica (Hegelm.) Hegelm. (Bot. Jahrb. Syst. 21: 288, 1895); \\ Spirodela pleiorrbiza (F.Muell. ex Kurz) Hegelm. (Bot. Jahrb. Syst. 21: 288, 1895); \\ Spirodela punctata (G.Mey.) C.H. Thomps. (Rep. (Annual) Missouri Bot. Gard. 9: 28, 1898); \\ Spirodela sichuanensis M.G.Liu \& K.M.Xie (J. Southwest. Agric. Coll. (Chongqing) 4: 56, 1983); \\ Spirodela seemannii Hegelm. in herb. (STU - Stuttgart, Germany)*
}

Lemna aequinoctialis Welw. (Apont. 578, 1859)

Lemna obcordata Bojer (Hortus Maurit. 358, 1837);

Lemna minor Griff. (Not. Pl. Asiat. 3: 216, 1851) et auct. mult;

Lemna anqolensis Welw. (J. Bot. 3: 112, 1865);

Lemna perpusilla var. trinervis Austin (Manual ed. 5: 479, 1867);

Lemna paucicostata Hegelm. (Lemnac. 138, 1868);

Lemna paucicostata var. membranacea Hegelm. (Lemnac. 141, 1868);

Lemna trinervis (Austin) Small (Fl. S.E. U.S. 230, 1903) et auct.;

Lemna minima Blatt. \& Hallb. (J. Indian Bot. 2: 50, 1921);

Lemna blatteri McCann (J. Bombay Nat. Hist. Soc. 42: 153, 1942);

Lemna eleanorae McCann (J. Bombay Nat. Hist. Soc. 42: 154, 1942);

Lemna aoukikusa T.Beppu \& Murata (Acta Phytotax. Geobot. 36: 55, 1985);

Lemna aoukikusa subsp. bokurikuensis T.B eppu \& Murata (Acta Phytotax. Geobot. 36: 56, 1985);

Lemna paucicostata var. subsymetrica Hegelm. in herb. (STU - Stuttgart, Germany)*;

Lemna monandra Wight in herb. (LE - Saint Petersburg, Russia)*;

Lemna obliqua Sutter in herb. (MO - Saint Louis, Missouri, USA)*;

Lemna perpusilla auct.*;

Lemna perpusilla var. paucicostata Hegelm.*

Lemna disperma Hegelm. (Bot. Z. 29: 654, 1871)

Lemna disperma var. fallax Hegelm. (Bot. Jahrb. Syst. 21: 291, 1895);

Lemna minor var. gunnii Hegelm. (Bot. Jahrb. Syst. 21: 292, 1895);

Lemna biovulata Hegelm. in herb. (STU - Stuttgart, Germany)*

Lemna gibba L. (Sp. PI. 970, 1753)

Lemna vulgaris Lam. (Fl. Franç. (Lamarck) 2: 189, 1779) [1778 publ. after 21 Mar 1779];

Lenticula gibba Lam. (Fl. Franç. (Lamarck) 2: 189, 1779) [1778 publ. after 21 Mar 1779]; 
Lenticula gibba (L.) Moench (Methodus 319, 1794);

Lenticula gibbosa P. Renault (Fl. Orne 40, 1803);

Thelmatophace gibba (L.) Schleiden (Linnaea 13: 391, 1839);

Lemna trichorrbiza Thuill. ex Schleid. (Linnaea 13: 391, 1839)

Thelmatophace gibbosa (P. Renault) Montandon (Guide Bot. 308, 1868);

Lemna cordata Sessé \& Moc. (Pl. Nov. Hisp. 159, 1890);

Thelmatophace generalis E.H.L. Krause (Deutschl. Fl. ed. 2, 1: 184, 1906);

Lemna parodiana Giardelli (Notas Mus. La Plata, Bot. 2: 97, 1937);

Lemna tertiaria (fossil near L. gibba) Dorofeev (Akad. Nauk SSSR 129-130, 1963);

Lemna symmeter G. Giuga (1973)*

Lemna japonica Landolt (Veröff. Geobot. Inst. ETH Stiftung Rübel Zürich 70: 23, 1980)

Lemna leiboensis M.G. Liu \& C.H.Hou (J. Southwest. Agric. Coll. (Chongqing) 4: 58, 1983)

Lemna minor L. (Sp. PI. 970, 1753)

Lenticula aquatica Brunfels (1530*;

Lenticula palustris H. Bock (1539)*;

Lenticula vulgaris Hill (1757)*;

Lenticula palustris Garsault (Fig. Pl. Méd. t. 336, 1764);

Lenticula minor (L.) Scop. (Fl. Carniol. ed. 2: 213, 1772);

Hydrophace monorrbiza Haller ex Scop. (Fl. Carniol. ed 2: 213, 1772);

Lenticula vulgaris Lam. (Fl. Franç. 2: 189, 1779);

Lemna vulgaris (Lam.) Lam. (Encycl. 3: 464, 1792);

Lemna minima Thuill. ex P.Beauv. (J. Phys. Chim. Hist. Nat. Élément 82: 113, 1816);

Lemna palustris Haenke ex Mert. \& W.D.J.Koch (Deutschl. Fl. ed. 3 (1):295, 1823);

Lemna minor var. minima Chev. (Fl. Gén. Env. Paris 2: 256, 1827);

Lemna cyclostasa Elliott ex Schleiden (Fl. Gén. Env. Paris 2: 256, 1827);

Lemna conjugata Willd. ex Schleiden (Linnaea 13: 391, 1839);

Lemna minima Chev. ex Schleiden (Linnaea 13: 385-392, 1839);

Lemna minuta Kunth ex Schleid. (1839)*

Lemna trichorrbiza Thuiller ex Schleid. (1839) in herb. (G - Genève, Switzerland)*;

Lemna minima Kunth (Enum. Pl. 3: 2-7, 1841);

Lemna ovata A.Br. ex C.Krauss (Flora 28: 344, 1845);

Lenticula minima Humb. \& Kunth ex Miq. (1855)*;

Lenticula minima (Chev.) Kurz (J. Linn. Soc., Bot. 9: 266, 1866);

Lemna minor var. oxymitra Hegelm. (Lemnac. 143, 1868);

Lemna minor var. colorata Hegelm. (Lemnac. 144, 1868);

Lenticularia monorbiza Montandon (Guide Bot. 308, 1868);

Hydrophace minor (L.) Bubani (Fl. Pyren. 4: 23, 1901);

Lemna minor var. latiuscula Domin (Sber. Kgl. Böhm. Gesell. Wiss. Prag, 1903);

Lemna blatteri McCann (J. Bomb. Nat. Hist. Soc. 43 (2), 1942);

Lemna minor II (in Landolt, Ber. Schweiz. Bot. Ges. 67: 271-410, 1957);

Lemna monorrbiza Montandon ex Daubs (Illinois Biol. Monogr. 34, 1965);

Lemna rwandensis De Sloover (Bull. Jard. Bot. Natl. Belg. 43: 366, 1973);

Lemna elliptica Opiz in herb. (BR - Meise, Belgium)*;

Lemna macrorrbiza Pers. in herb. (MO - Saint Louis, Missouri, USA)*;

Lemna minuta Kunth (Nov. Gen. Sp. 1: 372, 1817)

Lemna minima Chev. (Fl. Gén. Env. Paris 2: 256, 1827);

Lemna minima Phil. (Linnaea 29: 1-47, 1857);

Lemna minima Humb. ex Phil. (1865)*;

Lemna valdiviana var. minima Hegelm. (Lemnac. 138, 1868);

Lemna valdiviana var. abbreviata Hegelm. (Fl. Bras. 3(2): 19, 1878);

Lemna abbreviata (Hegelm.) Hegelm. (Bot. Jahrb. Syst. 21: 298, 1895); 
Lemna minima (Hegelm.) Phil. ex Hegelm. (Bot. Jahrb. Syst. 21: 299, 1895);

Lemna paludicola Kiener (1941)*;

Lemna minuscula Herter (Revista Sudamer. Bot. 9: 185, 1954);

Lemna abbreviata Reineck in herb. (LY - Lyon, France)*;

Lemna reticulata Phil. in herb. (BR - Meise, Belgium; STU - Stuttgart, Germany)*

Lemna obscura (Austin) Daubs (Illinois Biol. Monogr. 34: 20, 1965)

Lemna minor var. obscura Austin (Manual ed. 5: 479, 1867);

Lemna minor var. orbiculata Austin (Manual ed. 5: 479, 1867);

Lemna minor var. colorata (Lemnac. 144, 1868);

Lemna ecuadoriensis Landolt (Veröff. Geobot. Inst. ETH Stiftung Rübel Zürich 70: 22, 1980);

Lemna gibba var. americana Austin in herb. (STU - Stuttgart, Germany)*;

Lemna gibboides Landolt*;

Lemna perpusilla var. subsolida Austin in herb. (STU - Stuttgart, Germany)*

Lemna perpusilla Torr. (FI. New York 1: 245, 1843)

Lemna perpusilla var. trinervis Austin (Manual ed. 5: 479, 1867);

Hydrophace perpusilla (Torr.) Lunell (Amer. Midl. Naturalist 4: 237, 1915);

Lemna trinervis auct.*

Lemna tenera Kurz 1871

Staurogeton tener (Kurz) (Tzvelev, Bot. Zhurn. (Moscow \& Leningrad) 84(7): 114, 1999)

Lemna trisulca L. (Sp. PI. 970, 1753)

Hederula aquatica Lobel (1579)*;

Lenticula aquatica trisulca C.Bauhin (1623)*;

Lenticula aquatica trisulca Hill (1757)*;

Lenticula trisulca (L.) Scop. (Fl. Carniol. ed. 2, 2: 213, 1772);

Lenticula ramosa Lam. (Fl. Franç. 2: 189, 1779);

Lemna cruciata Roxb. (Fl. Ind. ed. 1832 3: 566, 1832);

Lemna intermedia Ruthe (Fl. Mark Brandenburg ed. 2: 277, 1834);

Staurogeton trisulcus (L.) Schur (Verh. Mitth. Siebenbürg. Vereins Naturwiss. Hermannstadt 4: 70, 1853);

Lemna bisulca Veesenm. (Beitr. Pflanzenk. Russ. Reiches 9: 104, 1854);

Lenticula cruciata Roxb. ex Miq. (1855)*;

Staurogeton trisulcum Montandon (Guid. Bot. 308, 1868);

Lemna trisulca var. pigmaea Henn. (Verh. Bot. Vereins Prov. Brandenburg 33: 8, 1891);

Hydrophace trisulca (L.) Bubani (Fl. Pyren. 4: 23, 1901);

Lemna trisulca var. linearis Asch. \& Graebn. (Syn. Mitt. Eur. Fl. 2: 392, 1904);

Lemna trisulca var. sagittata Makino (J. Jap. Bot. 3: 10, 1926)

Lemna turionifera Landolt (Aquatic Bot. 1: 355, 1975)

Lemna minor var. oxymitra Hegelm. (Lemnac. 143, 1868);

Lemna minor var. colorata Hegelm. (Lemnac. 144, 1868);

Lemna minor I (in Landolt, Ber. Schweiz. Bot. Ges. 67: 271-410, 1957)

\section{Lemna valdiviana Phil. (Linnaea 33: 239, 1864)}

Lemna minuta Raf. (Med. Repos. Original Essays Intelligence Phys. 5: 353, 1808);

Lemna minor var. cyclostasa Elliott (Sketch Bot. S. Carolina 2: 518, 1824);

Lemna torreyi Austin (Manual ed. 5: 479, 1867);

Lemna valdiviana var. pellucida Hegelm. (Lemnac. 138, 1868);

Lemna valdesiana S.Watson (U.S. Geol. Expl. 40 ${ }^{\text {th }}$ parallel 336, 1871);

Lemna valdiviana var. platyclados Hegelm. (Fl. Bras. 3(2): 20, 1878);

Lemna platyclados (Hegelm.) Hegelm. (Bot. Jahrb. Syst. 21: 298, 1895);

Lemna valdiviana var. robusta Hegelm. (Bot. Jahrb. Syst. 21: 298, 1895);

Lemna cherokensis Schwein. ex Hegelm. (Bot. Jahrb. Syst. 21: 298, 1896); 
Lemna cyclostasa Elliott ex W.Thomps. (Rep. (Annual) Missouri Bot. Gard. 9: 35, 1898);

Lemna aequilatera Hegelm. in herb. (STU - Stuttgart, Germany)*;

Lemna membranacea Hegelm. in herb. (STU - Stuttgart, Germany)*;

Lemna valdiviana f. gigantea Hegelm. in herb. (STU - Stuttgart, Germany)*

Lemna yungensis Landolt (Bull. Geobot. Inst. ETH 64: 18, 1998)

no synonym known

Spirodela intermedia W.Koch (Ber. Schweiz. Bot. Ges. 41: 114, 1932)

Lemna polyrrbiza var. maxima Griseb. (1879);

Spirodela biperforata W.Koch (Ber. Schweiz. Bot. Ges. 42: 188, 1933);

Lemna montevidensis Phil. in herb. (LY - Lyon, France)*

Spirodela polyrhiza (L.) Schleid. (Linnaea 13: 392, 1839)

Lemna polyrbiza L. (Sp. Pl. 970, 1753);

Lenticula major Hill (Brit. Herb.: 531, 1757);

Lenticula polyrrbiza (L.) Lam. (Fl. Franç. 2: 189, 1779);

Lemna orbicularis Kit. ex Schult. (Oestr. Fl. ed. 2, 1: 64, 1814);

Lemna obcordata P.Beauv. (J. Phys. Chim. Hist. Nat. Arts 82: 113, 1816);

Lemna thermalis P.Beauv. (J. Phys. Chim. Hist. Nat. Arts 82: 102, 113, 1816);

Lemna thermalis P.Beauv. ex Nutt. (Gen. N. Amer. Pl. 1: 19, 1818);

Lemna major C.A.Mey. (Ind. Cauc., 1831);

Lemna orbiculata Roxb. (Fl. Ind. ed. 1832 3: 565, 1832);

Lemna banatica Waldst. \& Kit. ex Schleid. (Linnaea 13: 392, 1839);

Telmatophace polyrrbiza (L.) Godr. (Fl. Lorraine 3: 18, 1844);

Lemna major Griff. (Not. Pl. Asiat. 3: 216, 1851);

Telmatophace orbicularis (Kitt. ex Schult.) Schur (Verh. Mitth. Siebenbürg. Vereins Naturwiss. Hermannstadt 4: 70, 1853);

Lemna transsilvanica Schur (Enum. Pl. Transsilv. 635, 1866);

Lemna polyrrbiza var. concolor Kurz (J. Bot. 5: 115, 1867);

Spirodela atropurpurea Montandon (Guide Bot. 309, 1868);

Lemna umbonata A.Br. ex Hegelm. (Lemnac. 156, 1868);

Lemna polyrrbiza var. parva Asch. \& Graebn. (Synop. Mitteleurop. Fl. 2(2): 395, 1904);

Lemna polyrrhiza var. magna Asch. \& Graebn. (Synop. Mitteleurop. Fl. 2(2): 395, 1904);

Lemna maxima Blatt. \& Hallb. (J. Indian Bot. 2: 49, 1921);

Spirodela maxima (Blatt. \& Hallb.) McCann (J. Bombay Nat. Hist. Soc. 43: 158, 1942);

Spirodela polyrrbiza var. masonii Daubs (Illinois Biol. Monogr. 34: 13, 1965)

Wolffia angusta Landolt (Veröff. Geobot. Inst. ETH Stiftung Rübel Zürich 70: 29, 1980)

no synonym known

Wolffia arrhiza (L.) Horkel ex Wimm. (FI. Schles. ed. 3: 140, 1857)

Lemna arrbiza L. (Mant. Pl. 2: 294, 1771);

Lenticula arrbiza (L.) Lam. (Fl. Franç. 2: 190, 1779);

Lemna arrbiza Mich. ex Schleiden (Linnaea 13: 385-392, 1839);

Wolffa michelii Schleid. (Beitr. Bot. 233, 1844);

Wolffia delilii Miq. (Ned. Kruidk. Arch. 3: 429, 1855);

Bruniera vivipara Franch. (Billotia 1: 25, 1864);

Lemna microscopica Schur (Enum. Pl. Transsilv. 635, 1866);

Telmatophace arrbiza Schur (Enum. Pl. Transsilv. 635, 1866);

Horkelia arrbiza (L.) Druce (Fl. Berkshire 511, 1898)

Wolffia australiana (Benth.) Hartog \& Plas (Blumea 20: 151, 1972)

Wolffia arrbiza var. australiana Benth. (Fl. Austral. 7: 162, 1878);

Wolffia hegelmaieri F.Muell. in herb. (STU - Stuttgart, Germany)* 
Wolffia borealis (Engelm. ex Hegelm.) Landolt (Veröff. Geobot. Inst. ETH Stiftung Rübel Zürich 44: 137, 1977) Wolffia brasiliensis var. borealis Engelm. ex Hegelm. (Lemnac. 127, 1868);

Wolffia punctata auct. amer*

Wolffia brasiliensis Wedd. (Ann. Sci. Nat., Bot. III, 12: 170, 1849)

Wolffia punctata Griseb. (Fl. Brit. W. I. 512, 1864);

Grantia brasiliensis (Wedd.) MacMill. (Metasp. Minnesota Valley 134, 1892);

Wolffia papulifera C.H.Thomps. (Rep. (Annual) Missouri Bot. Gard. 1898: 40, 1898);

Bruniera punctata Nieuwl. (Amer. Midl. Naturalist 2: 306, 1912)

Wolffia columbiana H.Karst. (Bot. Unters. 1: 103, 1865)

Grantia columbiana (H.Karst.) MacMill. (Metasp. Minnesota Valley 135, 1892);

Bruniera columbiana Nieuwl. (Amer. Midl. Naturalist 2: 306, 1912);

Wolffia robbinsii Austin in herb. (PH - Philadelphia, Pennsylvania, USA);

Wolffia veseiculosa Austin in herb. (STU - Stuttgart, Germany)

Wolffia cylindracea Hegelm. (Lemnac. 123, 1868)

no synonym known

Wolffia elongata Landolt (Veröff. Geobot. Inst. ETH Stiftung Rübel Zürich 70: 27, 1980)

no synonym known

Wolffia globosa (Roxb.) Hartog \& Plas (Blumea 18: 367, 1970)

Lemna globosa Roxb. (Fl. Ind. ed. 1832 3: 565, 1832);

Grantia globosa (Roxb.) Griff. (Hort. Suburb. Calcutt. 692, 1845);

Wolffia schleideni Miq. (Ned. Kruidk. Arch. 3: 428, 1855);

Wolffia delilii Kurz (J. Linn. Soc. Bot. 9: 265, 1866);

Wolffia delilii var. schleideni Kurz (J. Linn. Soc. Bot. 9: 265, 1866);

Thelmatophace cylindracea Welw. ex Hegelm. (Lemnac. 123, 1868);

Wolffia cylindracea Hegelm. (Lemnac. 123, 1868)

Wolffia microscopica (Griff.) Kurz (J. Linn. Soc., Bot. 9: 265, 1866)

Grantia microscopica Griff. (Hort. Suburb. Calcutt. 692, 1845)

Wolffia neglecta Landolt (Ber. Geobot. Inst. E. T. H. Stiftung Rübel 60: 147, 1994)

no synonym known

Wolffiella caudata Landolt (Ber. Geobot. Inst. E. T. H. Stiftung Rübel 58: 121, 1992)

no synonym known

Wolffiella denticulata (Hegelm.) Hegelm. (Bot. Jahrb. Syst. 21: 305, 1895)

Wolffia denticulata Hegelm. (Lemnac. 133, 1868)

Wolffiella gladiata (Hegelm.) Hegelm. (Bot. Jahrb. Syst. 21: 304, 1895)

Wolffia gladiata Hegelm. (Lemnac. 133, 1868);

Wolffia gladiata var. floridana J.D.Sm. (Bull. Torrey Bot. Club 7: 64, 1880);

Wolffia floridana (J.D.Sm.) O.D.Sm. ex Hegelm. (Bot. Jahrb. Syst. 21: 305, 1895);

Wolffiella floridana (J.D.Sm.) Thomps. (Rep. (Annual) Missouri Bot. Gard. 1898: 37, 1898)

Wolffiella hyalina (Delile) Monod (Mém. Soc. Hist. Nat. Afrique N Hors-ser. 2: 242, 1949)

Lemna byalina Delile (Descr. Egypte, Hist. Nat. 4: 27, 1813);

Wolffia delilei Schleid. (Linnaea 13: 390, 1839);

Wolffia byalina (Delile) Hegelm. (Lemnac. 128, 1868);

Wolffiella monodii Ast (Bull. Inst. Fondam. Afrique Noire, Sér. A, Sci. Nat. 30: 837, 1968); 
Pseudowolffia byalina (Delile) Hartog \& Plas (Blumea 18: 366, 1970);

Pseudowolffia monodii (Ast) Hartog \& Plas (Blumea 18: 366, 1970)

Wolffiella lingulata (Hegelm.) Hegelm. (Bot. Jahrb. Syst. 21: 303, 1895)

Wolffia lingulata Hegelm. (Lemnac. 132, 1868)

Wolffiella neotropica Landolt (Veröff. Geobot. Inst. ETH Stiftung Rübel Zürich 70: 26, 1980)

no synonym known

Wolffiella oblonga (Phil.) Hegelm. (Bot. Jahrb. Syst. 21: 303, 1895)

Lemna oblonga Phil. (Linnaea 29: 45, 1858);

Wolffia oblonga (Phil.) Hegelm. (Lemnac. 131, 1868);

Wolffia lingulata var. minor Hegelm. (Fl. Bras. 3(2): 10, 1878);

Wolffia gladiata var. abbreviata Kurtz (1891) in herb. (CORD - Córdoba, Argentina)*;

Wolffia oxyphylla Spegazzini in herb. (INTA - Castelar, Argentina)*;

Wolffiella kurtzii Thompson in herb. (KANU - Lawrence, Kansas, USA)*

Wolffiella repanda (Hegelm.) Monod (Mém. Soc. Hist. Nat. Afrique N Hors-ser. 2: 242, 1949)

Wolffia repanda Hegelm. (J. Bot. 3: 114, 1865);

Pseudowolffia repanda (Hegelm.) Hartog \& Plas (Blumea 18: 366, 1970)

Wolffiella rotunda Landolt (Veröff. Geobot. Inst. ETH Stiftung Rübel Zürich 70: 26, 1980)

no synonym known

Wolffiella welwitschii (Hegelm.) Monod (Mém. Soc. Hist. Nat. Afrique N Hors-ser. 2: 229, 1949)

Wolffia welwitschii Hegelm. (J. Bot. 3: 113, 1865);

Wolffia conguensis Welw. ex Trimen (J. Bot. 4: 223, 1866);

Wolffiopsis welwitschii den (Hegelm.) Hartog \& Plas (Blumea 18: 366, 1970);

Lemna revoluta L.A.Richard in herb. (STU - Stuttgart, Germany)* 